\title{
Interspecific differences in root architecture among maize and triticale genotypes grown under drought, waterlogging and soil compaction
}

\author{
Maciej T. Grzesiak • Agnieszka Ostrowska $\cdot$ Katarzyna Hura • \\ Grzegorz Rut · Franciszek Janowiak • Andrzej Rzepka • \\ Tomasz Hura $\cdot$ Stanisław Grzesiak
}

Received: 14 July 2014/Revised: 20 August 2014/ Accepted: 25 September 2014/Published online: 7 October 2014

(C) The Author(s) 2014. This article is published with open access at Springerlink.com

\begin{abstract}
Environmental stresses (soil compaction, drought, waterlogging) cause changes in plants' root system structure, also affecting the growth of above-ground parts. The aim of this study was to estimate phenotypic variation among maize and triticale genotypes in root penetration ability through petrolatum-wax-layer (RPA). Also, the effect of shortage or excess of soil water on dry matter of shoots and roots and morphological changes in root system structure in sensitive and resistant maize and triticale genotypes grown in low or high soil compaction level was evaluated. To estimate RPA index, the petrolatum-wax-layer method (PWL) was used. The strength of three petrolatum-wax concentrations 60,50 and $40 \%$ was $0.52,1.07$ and $1.58 \mathrm{MPa}$, respectively. High coefficients of variation $(\mathrm{CV})$ were observed in 0.52 and $1.07 \mathrm{MPa}$ and for maize were 19.2 and $21.7 \%$, and for triticale, 12.5 and $18.3 \%$, respectively. The data indicate that the use of PWL technique is an effective screening method, and makes it possible to divide the genotypes into resistant and sensitive groups. The second part of this study investigated a multistress effect of soil compaction combined with drought or
\end{abstract}

Communicated by W. Filek.

M. T. Grzesiak $(\bowtie) \cdot$ A. Ostrowska · F. Janowiak · T. Hura S. Grzesiak

The F. Górski Institute of Plant Physiology, Polish Academy of Sciences, Niezapominajek 21, 30-231 Cracow, Poland e-mail: m.grzesiak@ifr-pan.krakow.pl

\section{K. Hura}

Department of Plant Physiology, Agriculture University, Podłużna 3, 30254 Cracow, Poland

G. Rut · A. Rzepka

Department of Plant Physiology, Institute of Biology,

Pedagogical University, Podbrzezie 2, 30054 Cracow, Poland waterlogging on root and shoot growth and morphological changes in root system structure of maize and triticale genotypes differing in susceptibility to environmental stresses. Seedlings were grown for 4 weeks in root-boxes under conditions of low (LSC $1.1 \mathrm{~g} \mathrm{~cm}^{-3}$ ) or severe (SSC $1.6 \mathrm{~g} \mathrm{~cm}^{-3}$ ) soil compaction. Drought or waterlogging stresses were applied for 2 weeks from 14th to 28th day. In comparison to LSC treatment, in SSC treatment the decrease in dry matter of shoots and roots was greater for sensitive genotypes of maize and triticale (Ancora, CHD147). Soil drought or waterlogging caused greater decrease of dry matter of shoots and roots in seedlings grown in SSC in comparison to LSC. The root penetration index (RPI) was estimated as a ratio of root dry matter in $15-40 \mathrm{~cm}$ root-box layer to total root dry matter. On the basis of RPI it was possible to group the genotypes according to their ability to distribute roots in soil profile. In comparison to LSC, SSC exerted a strong influence on the length of seminal and seminal adventitious roots, as well as the number and length of L- and S-type lateral roots developed on seminal and nodal roots. In both species the restriction effect of soil compaction on number and length of roots was more severe in sensitive (Ankora, CHD-147) than in resistant (Tina, CHD-247) genotypes. The restriction in roots propagation was greater in triticale than in maize. Exposure to drought or waterlogging in the case of genotypes grown in LSC and SSC treatments caused a decrease in number and length of particular components of root system structure. In both species the decrease of root number and length in plants grown under waterlogging was greater than under drought. The observed changes in root system were greater in sensitive (Ankora, CHD147) than in resistant (Tina, CHD-247) genotypes. Statistically significant correlations were found between RPA and RPI and also between these indexes and soil compaction, drought 
and waterlogging susceptibility indexes. This indicates that genotypes resistant to soil compaction were resistant to drought or waterlogging and also that genotypes resistant to drought were resistant to waterlogging.

Keywords Triticale (x Triticosecale Witt) - Maize (Zea mays L.) · Petrolatum-wax layer (PWL) - Root penetration indexes (RPA, RPI) · Dry matter · Soil compaction · Soil drought $\cdot$ Soil waterlogging

$\begin{array}{ll}\text { Abbreviations } \\ \text { D } & \text { Drought } \\ \text { LSC } & \text { Low soil compaction level } \\ \text { RPA } & \text { Root penetration ability } \\ \text { RPI } & \text { Root penetration index } \\ \text { PWL } & \text { Petrolatum-wax layer } \\ \text { SSC } & \text { Severe soil compaction level } \\ \text { W } & \text { Waterlogging }\end{array}$

\section{Introduction}

Abiotic stresses, e.g., soil compaction, drought and waterlogging are environmental factors that affect plants growth, development and yield. Different levels of soil compaction are caused mainly by natural processes and by the use of heavy machinery in soil cultivation. With drought, we deal in circumstances when the amount of rainfall do not compensate the water loss through a transpiration and evaporation, and with waterlogging, when the soil is inundated as a result of heavy rainfalls or river floods what causes drastic decrease in roots capability to water uptake as a result of decrease in oxygen content in water (Masle 2002; Fageria et al. 2006). The degree of plant restriction by environmental stresses mainly depends on the species, variety and the age of the plants. The tolerance of plant species to stresses factors is determined by plants genes and their expression underlies interactions with actual meteorological conditions of the environment. The interand intraspecific variations between species and within genotypes in responses to those stresses are significant, however, problems related to a combined influence of different soil moisture with physical soil parameters have not been studied thoroughly (Kono et al. 1987b; Masle 2002; Ashraf 2010).

Plant physiologists and breeders search for the screening methods for selecting stress-resistant or sensitive genotypes (Hanson and Nelson 1985; Zagdanska 1992; Golbashy et al. 2010). A mathematical formulas for calculation of stress indexes can be found in studies by Fischer and Maurer (1978), Larsson and Górny (1988), Winter et al.
(1988) and Golbashy et al. (2010). Screening tests are expected to be easy, fast and inexpensive and ought to correlate significantly with the stress indexes obtained in plants grown in field conditions (Hanson and Nelson 1985; Royo et al. 2000; Chaves et al. 2002; Clark et al. 2003; Witta et al. 2012; Grzesiak et al. 2013). According to Yu et al. (1995) the first application of petrolatum-wax layer to estimation of the root penetration ability was by Taylor and Gardner (1960) and in this study we applied this method as a reference for estimation of a phenotypic variation in root penetration ability of maize and triticale genotypes.

Particular plants species develop morphologically different root systems. These morphological differences are usually closely connected with the physiological functions of the particular components of the root system. Root system structure may be characterized by the number, length, diameter of the particular root components, direction of extension of nodal roots and branching (rooting angle between plant axis and root) (Kono et al. 1987a, b; Yamauchi 1993; Grzesiak et al. 1999). The particular components of the plant root system show both similarities and differences in their functions. The lateral roots are responsible for the uptake of water and mineral components, while the main seminal and nodal roots are responsible for effective distribution of the laterals in the soil profile and water transport to green plant parts (Tardieu and Katerji 1991; Yamauchi 1993). According to Yamauchi (1993) cereal plants develop two types of the root systems, depending on the angle of growth of side branches-lateral roots and their distribution in a soil profile. "Concentrated" type of a root system develops a greater number of densely distributed nodal roots with relatively small rooting angle. Other type designated as a "scattered" develops fewer but longer nodal roots, many of which runs obliquely in the soil profile (larger rooting angle). Although it is reported that the responses of growth in each root type and architecture of root system to soil environmental stresses are different among plants with concentrated and scattered root system (Kono et al. 1987b; Yamauchi 1993; Iijima et al.1991; Chan and Weil 2010; Grzesiak et al. 1999, 2013). Typical responses of a plant root system structure to soil water content, temperature, soil compaction, $\mathrm{pH}$ is reduction in number, length of roots and restriction of downward penetration of the main root axes. Those changes accompanied by morphological changes in shoot include a decrease in plant height, leaf number, area and their thickness and changes in the shoot-to-root ratio dry mass and a decrease in grain yield (Clark et al. 2003; Fageria et al. 2006). Inhibited plant growth is mostly attributed to reduced rooting volume (Iijima and Kono 1991; Yamauchi 1993; Grzesiak et al. 1999, 2002; Masle 2002; Fageria et al. 2006). 
The physiological reasons associated with differential sensitivity of C3 and C4 plant species to environmental stresses (soil compaction different soil moisture) are not well-explained and understood (Nayyar and Gupta 2006, Grzesiak et al. 2012). The aim of this study was to examine the response of maize and triticale genotypes grown in low and high soil compaction levels and limited or excess soil water content on the growth of shoots and roots, ability of root penetration in soil profile and morphological changes in root system structure. The responses of maize and triticale genotypes to drought and waterlogging may explain how these species manage their growth under soil compaction.

\section{Materials and methods}

Plant materials

Experiments were carried out on eight single-cross maize hybrids and on eight strains and cultivars of spring triticale. Maize grain was obtained from Pioneer Overseas $\mathrm{GmbH}$ (Austria), Pioneer Saaten (Poland), Garst Seed Company (USA), Agriculture Canada and SEMPOL Holding (Slovakia). Triticale grain was obtained from DANKO in Choryn and from IHAR, Małyszyn (Poland). List of maize and triticale genotypes is presented in Table 1. Two experiments were conducted: experiment no. 1 was designed to test root penetration ability index (RPA) for eight maize and eight triticale genotypes and experiment no. 2 was designed to determine of changes of root morphological traits in two maize (Ankora, Tina) and two triticale (CHD-147, CHD-247) genotypes differing in susceptibility to environment stresses, e.g., drought, waterlogging and soil compaction.

\section{Growth conditions}

Plants were grown in air-conditioned growth cabinets under the following day/night conditions: temperature $25 / 18{ }^{\circ} \mathrm{C} \quad\left( \pm 2.5^{\circ} \mathrm{C}\right)$, relative humidity $(\mathrm{RH}) \quad 70 / 60 \%$ $( \pm 5 \%)$ and during a $14 \mathrm{~h}$ photoperiod from 7:00 to 21:00 (artificial irradiance from high pressure sodium lamps, Philips SON-T AGRO, $400 \mathrm{~W})$ PAR was equal to about $350 \mu \mathrm{mol} \mathrm{m} \mathrm{m}^{-2}$.

In experiment no. 1 petrolatum and wax layer (about $0.2 \mathrm{~cm}$ ) was used to create barrier for root growth, as described by Yu et al. (1995). Petrolatum (Paraffin pureAppliChem, GmbH, Danmark) and wax (Vasline whiteAppliChem, GmbH, Danmark) layer was varied by mixing melted of both substances in temperature about $80{ }^{\circ} \mathrm{C}$ in various proportions (v/v) 25:75, 35:65, and 40:60. The strength of three petrolatum and wax concentration in
$24{ }^{\circ} \mathrm{C}$ were about $0.52,1.07$ and $1.58 \mathrm{MPa}$. Seedlings were grown in two-part container. In an upper part $(8 \mathrm{~cm}$ high, $18 \mathrm{~cm}$ diameter) was placed a plastic grid $(0.5 \mathrm{~cm})$ to support petrolatum-wax layer and soil substrate (vermiculite). The bottom part of the container (13 cm high, 17.5 diameter) contained water solution of full strength Hoagland medium. Germinated grains were placed in the upper part about $1.5 \mathrm{~cm}$ over plastic grid with petrolatum-wax layer. As a control treatment the container without petrolatum-wax layer was used. After 14 days of growth number of penetrated roots was determined. For each maize or triticale genotypes (16), treatment (4), five containers with five plants were used.

In experiment no. 2 seedlings of maize (Anova, Tina) and triticale (CHD147, CHD-247) were grown in rootboxes, what enabled the non-destructive isolation of all components of the root system (Kono et al. 1987a). The set of a "root-box and pin board method" consists of: a plexiglass root box (width, $0.25 \mathrm{~m}$; depth, $0.40 \mathrm{~m}$; thickness, $0.02 \mathrm{~m}$ ), a pin board for sampling the root system, and a polyethylene sheet (envelope) for handling and preserving the root system. Root boxes were filled with a mixture of garden soil-loamy soil $(85 \%)$ and silt-sand loam (15\%), peat and sand (1:1:3-v:v:v). Air-dried soil substrate was sieved in a $0.25 \mathrm{~cm}$ mesh and mixed with a compound fertilizer (N, $28 \mathrm{mg}$; P, $18 \mathrm{mg}$; K, $14 \mathrm{mg}$ ) at the rate per $1 \mathrm{~kg}$ of the soil substrate.

Two levels of soil compaction were applied: LSC (low) and SSC (severe) and for those treatments, the air-dried soil bulk densities throughout the $0-40 \mathrm{~cm}$ soil profile were set at 1.10 and $1.58 \mathrm{~g} \mathrm{~cm}^{-3}$. Mechanical impedance in soil substrate was measured with penetrometer DIK 5520 (Daiki Rika Kogyo Co. Ltd, Japan). Soil pore distribution was divided into five classes of pore diameter $(>350$, 100-350, 25-100, 10-25 and $<10 \mu \mathrm{m})$. Total pore size, in percent of soil volume for treatments LSC, and SSC was 53.5 and $47.2 \%$, respectively. Soil substrate $\mathrm{pH}$ was about 7.1 and percent of organic material was 0.7 .

Field soil water capacity (FWC) for soil mixture was determined according to Kopecky methods. Air-drained soil samples (110.0 and $160.0 \mathrm{~g}$ ) were placed inside metal cylinders, with the $1 \mathrm{~mm}$ hole at the bottom. For all samples, volume was $100 \mathrm{~cm}^{3}$. Cylinders with samples were placed inside the container with water for $30 \mathrm{~min}$. After $8 \mathrm{~h}$, maximal soil water content in samples was 0.47 and $0.39\left(\mathrm{~g} \mathrm{~cm}^{-3}\right)$, respectively, and after $48 \mathrm{~h}$ decreased to 0.25 and $0.18\left(\mathrm{~g} \mathrm{~cm}^{-3}\right)$, respectively. According to Hillel and van Bavel (1976) those last values were assumed to be $100 \%$ of soil field water capacity (FWC). During the experiment the root-boxes were weighted every day, and the amount of the water loss through evapotranspiration was refilled to keep the constant mass of root-boxes in each treatment at a level of 65-70\% FWC. 


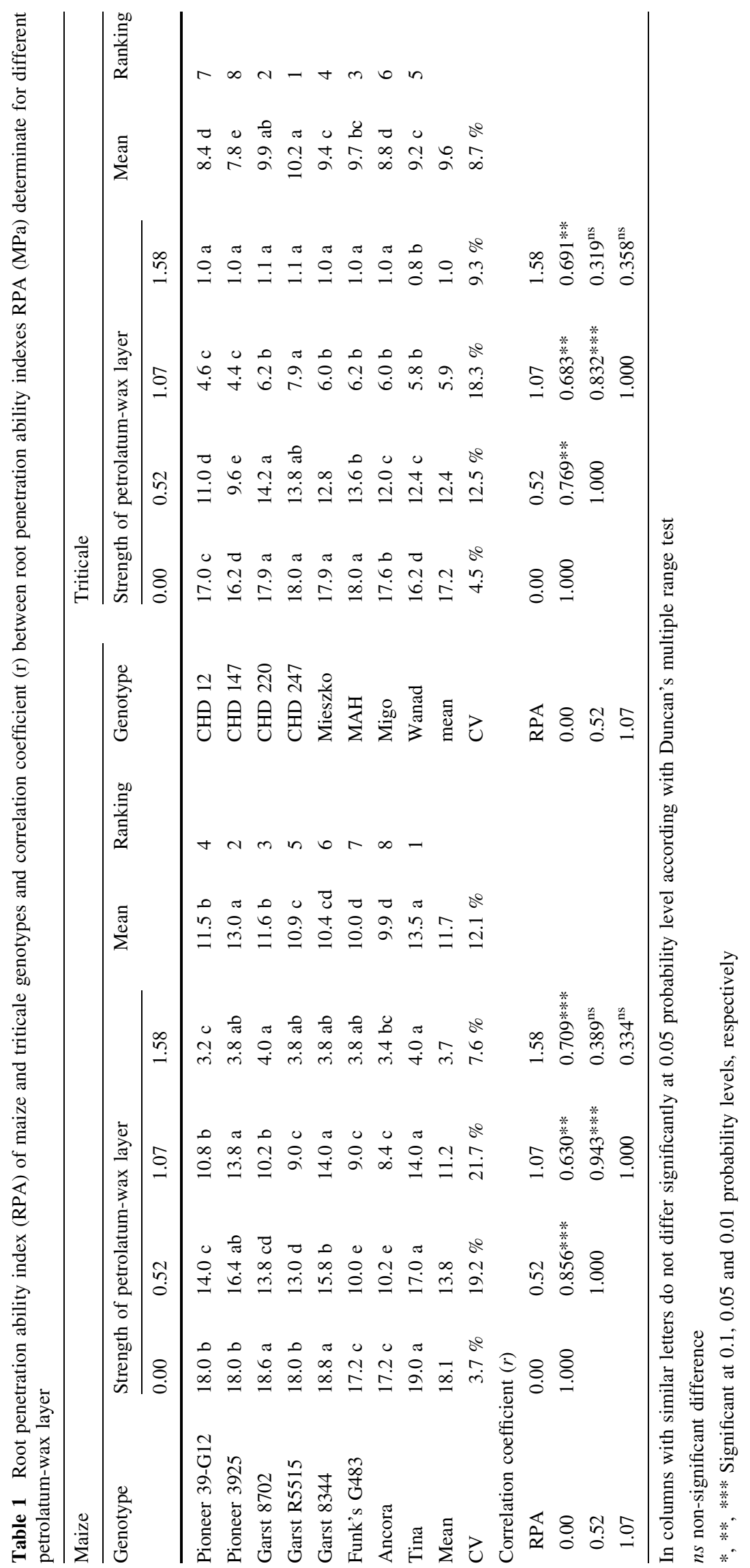


Table 2 Analysis of variance (ANOVA) for root penetration ability index (RPA) maize and triticale genotypes grown in four petrolatumwax concentrations

\begin{tabular}{lrrcrl}
\hline Source of variation & $d f$ & \multicolumn{1}{l}{ SS } & \multicolumn{1}{l}{ MS } & \multicolumn{1}{l}{$P$} \\
\hline Maize & & & & & \\
$\quad$ Intercept & 1 & $21,822.9$ & $21,822.91$ & $2,867.7$ & $0.00^{*}$ \\
Treatment (TR) & 3 & $4,334.4$ & $1,454.8$ & 191.2 & $0.00^{*}$ \\
Genotype (GE) & 7 & 276.6 & 39.52 & 5.2 & $0.00^{*}$ \\
TR $\times$ GE & 21 & 187.4 & 8.93 & 1.2 & 0.29 \\
Error & 128 & 974.1 & 7.61 & & \\
Triticale & & & & & \\
Intercept & 1 & $13,875.6$ & $13,875.6$ & $3,479.8$ & $0.00^{*}$ \\
Treatment (TR) & 3 & 54.29 .3 & $1,809.8$ & 453.9 & $0.00^{*}$ \\
Genotype (GE) & 7 & 106.5 & 15.2 & 3.8 & $0.00^{*}$ \\
TR $\times$ GE & 21 & 108.2 & 5.1 & 1.3 & 0.19 \\
Error & 128 & 510.4 & 4.0 & & \\
\hline
\end{tabular}

* Significant at $0.1,0.05$ and 0.01 probability levels, respectively

A single pre-germinated grain was planted at a depth of 3-4 cm. After 28 days of plants growth under LSC conditions in Zadoks scale was about 15 for maize and about 13 for triticale. On the 28th day of growth the seedling was cut into shoots and roots. The roots were sampled after the soil in the pot had been washed away by a gentle stream of water. Root samples were preserved in a FAA (formalin, acetic acid, and ethanol) solution.

In experiment no. 2 for control conditions soil water content was maintained from sowing to 28th day at the level of 65-70 \% FWC. For drought (D) or waterlogging (W) treatments from 14th to 28th day for D soil water content was kept at the level of 30-35\% FWC and for W soil water content was kept at the level of $100 \%$ FWC.

Measurements

For measurement of the number and length of root components, a digital image root analyzer (Delta T Scan, Delta
T Co., England) was used. Determination of the number and total length of L- and S-type roots was made only for seminal roots. The seminal roots were scanned and measurements were taken with application of light pen of electronic planimeter Microplan II (Laboratory computer Systems, Inc., Cambridge, Massachusetts). Classification of lateral roots into L-type or S-type was made according to root length. The L-type lateral root was long $(>2.0 \mathrm{~cm})$ and branching into the higher order lateral roots, while S-type was short $(<2.0 \mathrm{~cm})$ and non-branching.

Dry matter of shoot $(\mathrm{S})$ and roots $(\mathrm{R})$ were sampled in experiment no. 2. and were determined on the 28th day after sowing, after drying at $65{ }^{\circ} \mathrm{C}$ for $72 \mathrm{~h}$. Dry matter of roots was determined for separately three layers of soil substrate in root box $(0.0-15.0,15.0-30.0$, and $30.0-40.0 \mathrm{~cm}$ ). For each genotypes (4) and treatments (6) three root-boxes with one plants were used $(n=3)$.

Values of root penetration ability index (RPA) were calculated in experiment no. 1 as a ratio of number of roots penetrate petrolatum-wax layer per seedling $(n=5)$.

$\mathrm{RPA}=$ number of roots penetrate petrolatum layer/ number of seedlings

Index of root penetration (RPI) was calculated in experiment 2 according to the formula:

$\mathrm{RPI}=$ dry matter of root grown in soil profile from 15 to $40 \mathrm{~cm} /$ total root dry mater

Statistical analysis

All data were analyzed by one-way ANOVA using Statistica 10.0 (StatSoft, Inc., USA). Linear correlation analyses were used to determine the relationship between soil compaction stress indexes (SCSI) and drought susceptibility index (DSI) or waterlogging stress indices (WSI).
Table 3 Correlation coefficient $(r)$ between root penetration ability index (RPA) and soil compaction susceptibility index (SCSI), drought susceptibility index (DSI) and waterlogging susceptibility index (WSI)

See Grzesiak et al. 2014 in press $n s$ non-significant difference $*, * *, * * *$ Significant at 0.1 , 0.05 and 0.01 probability levels, respectively

\begin{tabular}{|c|c|c|c|c|c|c|}
\hline \multirow[t]{2}{*}{$\begin{array}{l}\text { Root penetration ability } \\
\text { index (RPA) }\end{array}$} & \multicolumn{2}{|c|}{$\begin{array}{l}\text { Soil compaction } \\
\text { susceptibility index } \\
\text { (SCSI) }\end{array}$} & \multicolumn{2}{|c|}{$\begin{array}{l}\text { Drought susceptibility } \\
\text { index (DSI) }\end{array}$} & \multicolumn{2}{|c|}{$\begin{array}{l}\text { Waterlogging } \\
\text { susceptibility index } \\
\text { (WSI) }\end{array}$} \\
\hline & LSC & SSC & LSC & SSC & LSC & SSC \\
\hline \multicolumn{7}{|l|}{ Maize } \\
\hline 0.52 & $-0.467^{\mathrm{ns}}$ & $-0.608^{\mathrm{ns}}$ & $-0.579^{\mathrm{ns}}$ & $-0.483^{\mathrm{ns}}$ & $-0.633 * *$ & $-0.608^{\mathrm{ns}}$ \\
\hline 1.07 & $-0.697 * *$ & $-0.686 * *$ & $-0.704 * *$ & $-0.710 * *$ & $-0.726 * *$ & $-0.688 * *$ \\
\hline 1.58 & $-0.518^{\mathrm{ns}}$ & $-0.675^{* *}$ & $-0.613 * *$ & $-0.552^{\mathrm{ns}}$ & $-0.648 * *$ & $-0.699 * *$ \\
\hline \multicolumn{7}{|l|}{ Triticale } \\
\hline 0.52 & $-0.523^{\mathrm{ns}}$ & $-0.534^{\mathrm{ns}}$ & $-0.371^{\mathrm{ns}}$ & $-0.487^{\mathrm{ns}}$ & $-0.387^{\mathrm{ns}}$ & $-0.305^{\mathrm{ns}}$ \\
\hline 1.07 & $-0.750 * *$ & $-0.537^{\mathrm{ns}}$ & $-0.510^{\mathrm{ns}}$ & $-0.746^{* *}$ & $-0.711 * *$ & $-0.656^{* *}$ \\
\hline 1.58 & $-0.910 * * *$ & $-0.657 * *$ & $-0.833 * * *$ & $-0.870 * * *$ & $-0.908 * * *$ & $-0.882 * * *$ \\
\hline
\end{tabular}




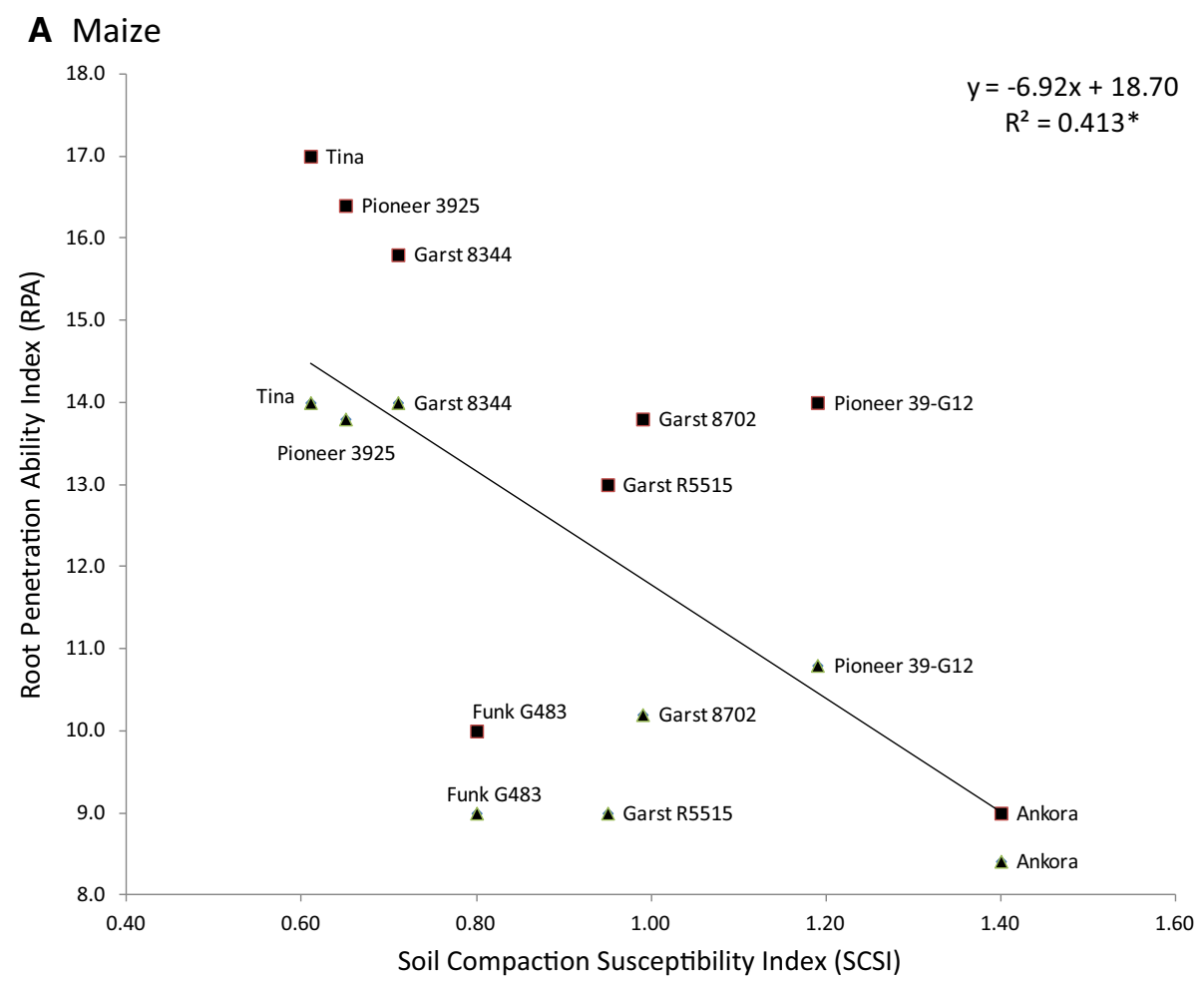

\section{B Triticale}

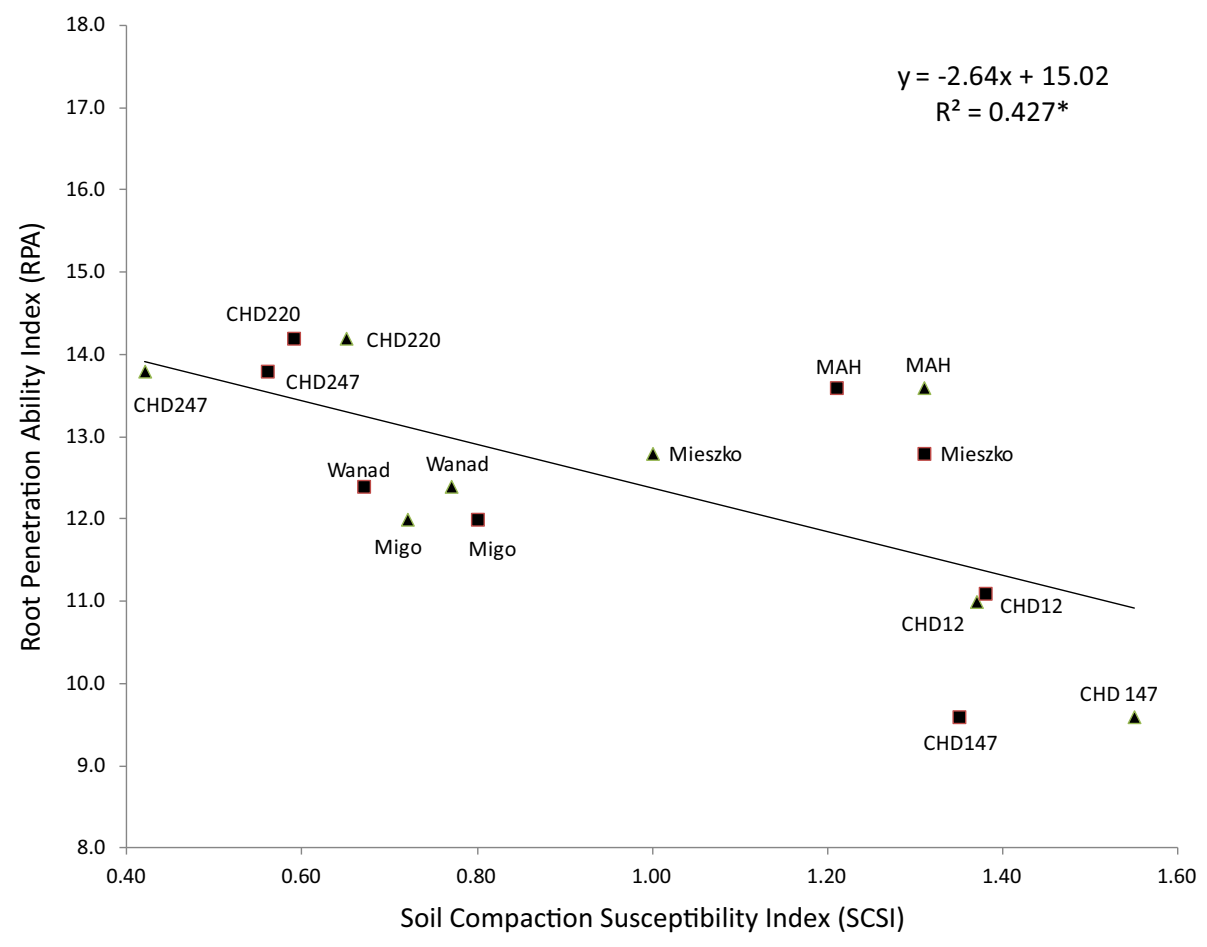

Fig. 1 Linear relationship between soil compaction susceptibility indexes (SCSI) and Root penetration ability indexes (RPA) of maize (a) and triticale (b) genotypes. Filled triangle 0.52 and filled square $1.07 \mathrm{MPa}$ 
Table 4 Effects of soil compaction (SC), soil drought (D) and soil waterlogging (W) stresses on a dry matter of shoots (S) and roots (R), total seedlings dry matter $(\mathrm{S}+\mathrm{R})$ and shoot to root ratio $(\mathrm{S} / \mathrm{R})$ of sensitive (Ankora, CHD-147) and resistant (Tina, CHD-247) genotypes of maize and triticale

\begin{tabular}{|c|c|c|c|c|c|}
\hline \multirow[t]{2}{*}{ Treatment } & \multirow[t]{2}{*}{ Genotype } & \multicolumn{4}{|c|}{ Dry matter (g plants $\left.{ }^{-1}\right)$} \\
\hline & & Shoot $(\mathrm{S})$ & Root $(\mathrm{R})$ & $\mathrm{S}+\mathrm{R}$ & $\mathrm{S} / \mathrm{R}$ \\
\hline \multicolumn{6}{|l|}{ Maize } \\
\hline \multirow[t]{2}{*}{ LSC } & Ankora & $6.70 \mathrm{a}$ & $2.65 \mathrm{~b}$ & $9.35 \mathrm{a}$ & $2.53 \mathrm{c}$ \\
\hline & Tina & $5.90 \mathrm{c}$ & $2.84 \mathrm{a}$ & $8.74 \mathrm{~b}$ & $2.08 \mathrm{~d}$ \\
\hline \multirow[t]{2}{*}{ SSC } & Ankora & $6.18 \mathrm{~b}$ & $2.48 \mathrm{c}$ & $8.66 \mathrm{bc}$ & $2.49 \mathrm{c}$ \\
\hline & Tina & $5.41 \mathrm{e}$ & $2.70 \mathrm{ab}$ & $8.11 \mathrm{e}$ & $2.00 \mathrm{~d}$ \\
\hline \multirow[t]{2}{*}{$\mathrm{LSC}+\mathrm{D}$} & Ankora & $6.23 \mathrm{~b}$ & $2.33 \mathrm{~cd}$ & $8.56 \mathrm{c}$ & $2.67 \mathrm{~b}$ \\
\hline & Tina & $5.65 \mathrm{~d}$ & $2.71 \mathrm{ab}$ & $8.35 \mathrm{~cd}$ & $2.09 \mathrm{~d}$ \\
\hline \multirow[t]{2}{*}{$\mathrm{SSC}+\mathrm{D}$} & Ankora & $4.87 \mathrm{f}$ & $1.84 \mathrm{e}$ & $6.71 \mathrm{f}$ & $2.64 \mathrm{~b}$ \\
\hline & Tina & $4.55 \mathrm{~g}$ & $2.27 \mathrm{~d}$ & $6.81 \mathrm{f}$ & $2.01 \mathrm{~d}$ \\
\hline \multirow[t]{2}{*}{$\mathrm{LSC}+\mathrm{W}$} & Ankora & $6.06 \mathrm{c}$ & $2.20 \mathrm{~d}$ & $8.26 \mathrm{~cd}$ & $2.76 \mathrm{a}$ \\
\hline & Tina & $5.60 \mathrm{~d}$ & $2.73 \mathrm{ab}$ & $8.33 \mathrm{~cd}$ & $2.06 \mathrm{~d}$ \\
\hline \multirow[t]{2}{*}{$\mathrm{SSC}+\mathrm{W}$} & Ankora & $4.58 \mathrm{~g}$ & $1.64 \mathrm{f}$ & $6.22 \mathrm{~g}$ & $2.80 \mathrm{a}$ \\
\hline & Tina & $4.41 \mathrm{~g}$ & $2.40 \mathrm{c}$ & $6.80 \mathrm{f}$ & $1.84 \mathrm{e}$ \\
\hline \multicolumn{6}{|l|}{ Triticale } \\
\hline \multirow[t]{2}{*}{ LSC } & CHD 147 & $3.68 \mathrm{a}$ & $1.95 \mathrm{c}$ & $5.63 \mathrm{a}$ & $1.89 \mathrm{ab}$ \\
\hline & CHD 247 & $3.38 \mathrm{~b}$ & $2.18 \mathrm{a}$ & $5.56 \mathrm{a}$ & $1.55 \mathrm{c}$ \\
\hline \multirow[t]{2}{*}{ SSC } & CHD 147 & $2.83 \mathrm{e}$ & $1.59 \mathrm{e}$ & $4.42 \mathrm{de}$ & $1.78 \mathrm{~b}$ \\
\hline & CHD 247 & $2.95 \mathrm{e}$ & $2.01 \mathrm{~b}$ & $4.96 \mathrm{~b}$ & $1.47 \mathrm{~d}$ \\
\hline \multirow[t]{2}{*}{$\mathrm{LSC}+\mathrm{D}$} & CHD 147 & $3.17 \mathrm{c}$ & $1.64 \mathrm{e}$ & $4.81 \mathrm{c}$ & $1.93 \mathrm{a}$ \\
\hline & CHD 247 & $3.06 \mathrm{~d}$ & $1.93 \mathrm{c}$ & $4.99 \mathrm{~b}$ & $1.58 \mathrm{c}$ \\
\hline \multirow[t]{2}{*}{$\mathrm{SSC}+\mathrm{D}$} & CHD 147 & $2.35 \mathrm{~g}$ & $1.41 \mathrm{f}$ & $3.76 \mathrm{f}$ & $1.67 \mathrm{~b}$ \\
\hline & CHD 247 & $2.55 \mathrm{f}$ & $1.71 \mathrm{~d}$ & $4.26 \mathrm{e}$ & $1.49 \mathrm{~d}$ \\
\hline \multirow[t]{2}{*}{$\mathrm{LSC}+\mathrm{W}$} & CHD 147 & $3.08 \mathrm{~d}$ & $1.60 \mathrm{e}$ & $4.68 \mathrm{~d}$ & $1.93 \mathrm{a}$ \\
\hline & CHD 247 & $3.06 \mathrm{~d}$ & $1.92 \mathrm{c}$ & $4.98 \mathrm{~b}$ & $1.59 \mathrm{c}$ \\
\hline \multirow[t]{2}{*}{$\mathrm{SSC}+\mathrm{W}$} & CHD 147 & $2.25 \mathrm{~g}$ & $1.39 \mathrm{f}$ & $3.64 \mathrm{f}$ & $1.62 \mathrm{c}$ \\
\hline & CHD 247 & $2.57 \mathrm{f}$ & $1.72 \mathrm{~d}$ & $4.29 \mathrm{e}$ & $1.49 \mathrm{~d}$ \\
\hline
\end{tabular}

In columns with similar letters do not differ significantly at 0.05 probability level according to Duncan's multiple range test

\section{Results and discussion}

Root penetration ability index (RPA)

Our objective in experiment no. 1 was estimation of phenotypic variation in root penetration ability among maize and triticale genotypes. We used petrolatum-wax layer system that consists of different proportion of petrolatum to wax as screening method, according to Yu et al. (1995). The root penetration ability index (RPA) was measured as a ratio of the number of roots penetrating petrolatum-wax layer to the number of seedlings. The strength of three petrolatum-wax concentrations 60,50 and $40 \%$ were 0.52 , 1.07 and $1.58 \mathrm{MPa}$, respectively. As a control (0.00 $\mathrm{MPa})$
Table 5 Analysis of variance (ANOVA) for root penetration index (RPI) for sensitive (Ankora, CHD-147) and resistant (Tina, CHD 247) maize and triticale genotypes to environmental stresses

\begin{tabular}{|c|c|c|c|c|c|}
\hline Source of variation & $d f$ & SS & MS & $F$ & $P$ \\
\hline \multicolumn{6}{|l|}{ Maize } \\
\hline Intercept & 1 & 8.89 & 8.89 & $11,579.62$ & $0.000^{*}$ \\
\hline Genotype (GE) & 1 & 0.01 & 0.01 & 15.19 & $0.001 *$ \\
\hline Soil compaction (SC) & 1 & 0.01 & 0.01 & 8.77 & $0.007 *$ \\
\hline Treatment (TR) & 2 & 0.08 & 0.04 & 55.61 & $0.000 *$ \\
\hline $\mathrm{GE} \times \mathrm{SC}$ & 1 & 0.00 & 0.00 & 0.48 & 0.495 \\
\hline $\mathrm{GE} \times \mathrm{TR}$ & 2 & 0.00 & 0.00 & 4.04 & $0.031 *$ \\
\hline $\mathrm{SC} \times \mathrm{TR}$ & 2 & 0.00 & 0.00 & 0.29 & 0.751 \\
\hline $\mathrm{Ge} \times \mathrm{SC} \times \mathrm{TR}$ & 2 & 0.00 & 0.00 & 0.29 & 0.749 \\
\hline Error & 24 & 0.02 & 0.00 & & \\
\hline \multicolumn{6}{|l|}{ Triticale } \\
\hline Intercept & 1 & 6.57 & 6.57 & $1,801.74$ & $0.000 *$ \\
\hline Genotype (GE) & 1 & 0.02 & 0.02 & 4.54 & $0.044 *$ \\
\hline Soil compaction (SC) & 1 & 0.01 & 0.01 & 3.54 & 0.072 \\
\hline Treatment (TR) & 2 & 0.47 & 0.23 & 64.03 & $0.000 *$ \\
\hline $\mathrm{CE} \times \mathrm{SC}$ & 1 & 0.00 & 0.00 & 0.06 & 0.812 \\
\hline $\mathrm{GE} \times \mathrm{TR}$ & 2 & 0.00 & 0.00 & 0.63 & 0.543 \\
\hline $\mathrm{SC} \times \mathrm{TR}$ & 2 & 0.00 & 0.00 & 0.22 & 0.800 \\
\hline $\mathrm{Ge} \times \mathrm{SC} \times \mathrm{TR}$ & 2 & 0.00 & 0.00 & 0.19 & 0.827 \\
\hline Error & 24 & 0.09 & 0.00 & & \\
\hline
\end{tabular}

* Significant at $0.1,0.05$ and 0.01 probability levels, respectively

a container, only with plastic net but without petrolatumwax layer, was used.

The mean values of RPA index decreased for $0.00,0.52$, 1.07 , and $1.58 \mathrm{MPa}$ in maize by $18.1,13.8,11.2-3.7$, respectively, and in triticale: $17.2,12.4,5.9-1.0$, respectively (Table 1). High coefficients of variation (CV) were obtained for 0.52 and $1.07 \mathrm{MPa}$, in maize equaled 19.2 and $21.7 \%$, respectively, and for triticale 12.5 and $18.3 \%$, respectively. In both species correlation coefficient $\mathrm{r}$, between RPA treatments were statistically significant except 1.58 with 0.52 and $1.07 \mathrm{MPa}$ treatments. Analysis of variance ANOVA of RPA index is summarized in Table 2. For maize and triticale, treatment and genotype main effects were significant at 0.05 probability level, while genotype $\times$ treatment interaction was not significative for both species. In Table 3 and Fig. 1, linear correlation between RPA indexes and soil compaction, drought and waterlogging susceptibility indexes described in our earlier papers (Grzesiak et al. 2014 in press) are presented. Statistically significant negative linear correlation between RPA (0.52 and 1.07 MPa) and soil compaction susceptibility index SCSI (1.3 and $1.6 \mathrm{~g} \mathrm{~cm}^{-3}$ ) was found. On a basis of RPA it was shown, that the difference in root penetration ability occurred and that it is possible to divide the genotypes into resistant and sensitive group. For 0.52 
Table 6 Root dry matter in three levels of root-box soil profile and root penetration index (RPI) for sensitive (Ankora, CHD-147) and resistant to environmental stresses (Tina, CHD 247) of genotypes maize and triticale $($ mean $\pm \mathrm{SE}, n=3$ )

\begin{tabular}{|c|c|c|c|c|c|}
\hline \multirow[t]{2}{*}{ Genotype } & \multirow[t]{2}{*}{ Treatment } & \multicolumn{3}{|c|}{ Soil profile in root- box from top to bottom $(\mathrm{cm})$} & \multirow{2}{*}{$\begin{array}{l}\text { Root penetration } \\
\text { index (RPI) }\end{array}$} \\
\hline & & $0.0-15.0$ & $15.0-30.0$ & $30.0-40.0$ & \\
\hline \multicolumn{6}{|l|}{ Maize } \\
\hline \multirow[t]{6}{*}{ Ankora } & LSC & $1.19 \pm 0.05$ & $0.93 \pm 0.03$ & $0.53 \pm 0.03$ & $0.55 \pm 0.011$ \\
\hline & SSC & $1.23 \pm 0.04$ & $0.49 \pm 0.05$ & $0.76 \pm 0.04$ & $0.51 \pm 0.012$ \\
\hline & $\mathrm{LSC}+\mathrm{D}$ & $1.19 \pm 0.03$ & $0.91 \pm 0.05$ & $0.23 \pm 0.04$ & $0.49 \pm 0.018$ \\
\hline & $\mathrm{SSC}+\mathrm{D}$ & $1.01 \pm 0.05$ & $0.75 \pm 0.06$ & $0.08 \pm 0.02$ & $0.45 \pm 0.011$ \\
\hline & $\mathrm{LSC}+\mathrm{W}$ & $1.21 \pm 0.07$ & $0.83 \pm 0.08$ & $0.15 \pm 0.04$ & $0.45 \pm 0.011$ \\
\hline & $\mathrm{SSC}+\mathrm{W}$ & $0.92 \pm 0.06$ & $0.59 \pm 0.06$ & $0.13 \pm 0.03$ & $0.44 \pm 0.006$ \\
\hline \multirow[t]{6}{*}{ Tina } & LSC & $1.11 \pm 0.06$ & $1.08 \pm 0.05$ & $0.65 \pm 0.03$ & $0.61 \pm 0.006$ \\
\hline & SSC & $1.10 \pm 0.04$ & $1.05 \pm 0.04$ & $0.54 \pm 0.03$ & $0.59 \pm 0.003$ \\
\hline & $\mathrm{LSC}+\mathrm{D}$ & $1.35 \pm 0.08$ & $1.05 \pm 0.05$ & $0.31 \pm 0.05$ & $0.50 \pm 0.018$ \\
\hline & $\mathrm{SSC}+\mathrm{D}$ & $1.19 \pm 0.04$ & $0.93 \pm 0.07$ & $0.16 \pm 0.02$ & $0.48 \pm 0.011$ \\
\hline & $\mathrm{LSC}+\mathrm{W}$ & $1.44 \pm 0.06$ & $0.93 \pm 0.08$ & $0.35 \pm 0.06$ & $0.47 \pm 0.010$ \\
\hline & $\mathrm{SSC}+\mathrm{W}$ & $1.32 \pm 0.08$ & $0.82 \pm 0.07$ & $0.26 \pm 0.05$ & $0.45 \pm 0.007$ \\
\hline \multicolumn{6}{|l|}{ Triticale } \\
\hline \multirow[t]{6}{*}{ CHD-147 } & LSC & $0.80 \pm 0.05$ & $0.64 \pm 0.08$ & $0.51 \pm 0.09$ & $0.59 \pm 0.021$ \\
\hline & SSC & $0.70 \pm 0.04$ & $0.60 \pm 0.05$ & $0.29 \pm 0.06$ & $0.56 \pm 0.011$ \\
\hline & $\mathrm{LSC}+\mathrm{D}$ & $0.97 \pm 0.05$ & $0.38 \pm 0.05$ & $0.30 \pm 0.06$ & $0.41 \pm 0.028$ \\
\hline & $\mathrm{SSC}+\mathrm{D}$ & $0.92 \pm 0.04$ & $0.21 \pm 0.06$ & $0.28 \pm 0.01$ & $0.35 \pm 0.022$ \\
\hline & $\mathrm{LSC}+\mathrm{W}$ & $1.12 \pm 0.03$ & $0.40 \pm 0.07$ & $0.08 \pm 0.02$ & $0.30 \pm 0.034$ \\
\hline & $\mathrm{SSC}+\mathrm{W}$ & $1.03 \pm 0.05$ & $0.31 \pm 0.08$ & $0.06 \pm 0.02$ & $0.26 \pm 0.033$ \\
\hline \multirow[t]{6}{*}{ CHD-247 } & LSC & $0.85 \pm 0.07$ & $0.78 \pm 0.04$ & $0.55 \pm 0.08$ & $0.61 \pm 0.022$ \\
\hline & SSC & $0.86 \pm 0.04$ & $0.78 \pm 0.05$ & $0.36 \pm 0.06$ & $0.57 \pm 0.007$ \\
\hline & $\mathrm{LSC}+\mathrm{D}$ & $1.06 \pm 0.05$ & $0.56 \pm 0.08$ & $0.31 \pm 0.07$ & $0.45 \pm 0.031$ \\
\hline & $\mathrm{SSC}+\mathrm{D}$ & $1.03 \pm 0.04$ & $0.48 \pm 0.08$ & $0.21 \pm 0.09$ & $0.40 \pm 0.053$ \\
\hline & $\mathrm{LSC}+\mathrm{W}$ & $1.25 \pm 0.04$ & $0.52 \pm 0.09$ & $0.15 \pm 0.02$ & $0.35 \pm 0.033$ \\
\hline & $\mathrm{SSC}+\mathrm{W}$ & $1.12 \pm 0.06$ & $0.52 \pm 0.10$ & $0.09 \pm 0.02$ & $0.35 \pm 0.053$ \\
\hline
\end{tabular}

and 1.07 MPa soil impedance, in case of both species, rankings of genotypes according to their susceptibility were close or similar. Following maize genotypes were included in a sensitive group: Ankora, Pioneer 39-G12, in a moderate sensitivity Garst R5515, Garst 8702, and in a resistant group Tina, Pioneer 3925, Garst 8344. For triticale to a group a sensitive CHD-12,CHD-147, genotypes were included in a sensitive group, moderate sensitive Mieszko, MAH, Migo and resistant CHD-220, CHD-247, Wanad.

Mechanical impedance caused by compacted soil is a factor influencing root growth, elongation and proliferation (Tu and Tan 1991; Yu et al. 1995; Masle 2002). The ability of root to penetrate in soil profile can be beneficial in plants response to environmental stresses like soil compaction, drought or waterlogging; however, breeding for these traits is hindered by the lack of screening tests. In our experiment the petrolatum-wax layer consisted 40 and $50 \%$ petrolatum and 60 and $50 \%$ wax with the penetration resistance strength of 0.52 and $1.07 \mathrm{MPa}$ was satisfactory for estimation RPA index among maize and triticale genotypes. Root penetration ability varied both between and within crop species (Assaeed et al. 1990; Materechera et al. 1992; Kasperbauer and Busscher 1991; Masle 1992). Busscher et al. (1986) and Atwell (1993) suggested that soil strength about $1 \mathrm{MPa}$ affected root growth more than $2 \mathrm{MPa}$ : restricted root growth and reduced root length and root elongation. Glinski and Lipiec (1990) summarized the range of penetration ability for 14 plant species ranged from $0.3 \mathrm{MPa}$ for rice to $8.0 \mathrm{MPa}$ for ryegrass. Yu et al. (1995) used wax-petrolatum layer (1.4 MPa) to evaluate genetic variation in rice and found that roots of genotypes from drylands had greater ability to penetrate than wetland habitat and root penetrate ability was positively correlated with root thickness. Also differences in root penetration ability were found in dryland and wetland rice cultivars characterized as a semiaquatic species adapted to ecosystems ranging from flooding to dryland (O`Toole and Cruz 1983). O‘Toole and Cruz (1983) and Chang et al. (1986) suggested that leaf epicuticular wax and root thickness play role in root characteristic for drought stress tolerance and in root penetration ability. Cultivars from dryland tended to have thicker roots than cultivars from wetland habitats. 
Table 7 Analysis of variance (ANOVA) of root dry matter in three level of root box soil profile in maize and triticale genotypes
* Significant at $0.1,0.05$ and 0.01 probability levels, respectively

\begin{tabular}{|c|c|c|c|c|c|c|c|c|c|}
\hline \multirow[t]{2}{*}{ Source of variation } & \multirow[t]{2}{*}{$d f$} & \multicolumn{4}{|l|}{ Maize } & \multicolumn{4}{|c|}{ Triticale } \\
\hline & & SS & MS & $F$ & $P$ & SS & MS & $F$ & $P$ \\
\hline \multicolumn{10}{|c|}{ Profile of soil level $(0.0-15.0 \mathrm{~cm})$} \\
\hline Intercept & 1 & 50.838 & 50.83 & $3,532.50$ & $0.000^{*}$ & 34.235 & 34.235 & $1,560.87$ & $0.000 *$ \\
\hline Genotype (GE) & 1 & 0.146 & 0.146 & 10.156 & $0.004 *$ & 0.101 & 0.101 & 4.602 & $0.042 *$ \\
\hline $\begin{array}{l}\text { Soil compaction } \\
\text { (SC) }\end{array}$ & 1 & 0.132 & 0.132 & 9.161 & $0.006^{*}$ & 0.040 & 0.04 & 1.822 & 0.190 \\
\hline Treatment (TR) & 2 & 0.025 & 0.012 & 0.859 & 0.436 & 0.641 & 0.320 & 14.610 & $0.000 *$ \\
\hline $\mathrm{GE} \times \mathrm{SC}$ & 1 & 0.005 & 0.005 & 0.333 & 0.569 & 0.002 & 0.002 & 0.089 & 0.769 \\
\hline $\mathrm{GE} \times \mathrm{TR}$ & 2 & 0.276 & 0.138 & 9.579 & $0.001 *$ & 0.000 & 0.000 & 0.003 & 0.997 \\
\hline $\mathrm{SC} \times \mathrm{TR}$ & 2 & 0.087 & 0.043 & 3.019 & 0.068 & 0.009 & 0.005 & 0.209 & 0.813 \\
\hline $\mathrm{GE} \times \mathrm{SC} \times \mathrm{TR}$ & 2 & 0.017 & 0.008 & 0.578 & 0.569 & 0.009 & 0.005 & 0.213 & 0.810 \\
\hline Error & 24 & 0.345 & 0.014 & & & 0.526 & 0.022 & & \\
\hline \multicolumn{10}{|c|}{ Profile of soil level $(15.0-30.0 \mathrm{~cm})$} \\
\hline Intercept & 1 & 26.815 & 26.815 & 1.669 .102 & $0.000 *$ & 9.563 & 9.563 & 350.265 & $0.000 *$ \\
\hline Genotype (GE) & 1 & 0.448 & 0.448 & 27.867 & $0.000 *$ & 0.302 & 0.302 & 11.061 & $0.003 *$ \\
\hline $\begin{array}{l}\text { Soil compaction } \\
\text { (SC) }\end{array}$ & 1 & 0.307 & 0.307 & 19.136 & $0.000 *$ & 0.037 & 0.037 & 1.365 & 0.254 \\
\hline Treatment (TR) & 2 & 0.096 & 0.048 & 2.983 & 0.070 & 0.646 & 0.323 & 11.825 & $0.000 *$ \\
\hline $\mathrm{GE} \times \mathrm{SC}$ & 1 & 0.084 & 0.084 & 5.207 & $0.031 *$ & 0.011 & 0.011 & 0.418 & 0.524 \\
\hline $\mathrm{GE} \times \mathrm{TR}$ & 2 & 0.075 & 0.037 & 2.327 & 0.119 & 0.008 & 0.004 & 0.141 & 0.869 \\
\hline $\mathrm{SC} \times \mathrm{TR}$ & 2 & 0.013 & 0.006 & 0.396 & 0.677 & 0.017 & 0.009 & 0.317 & 0.731 \\
\hline $\mathrm{GE} \times \mathrm{SC} \times \mathrm{TR}$ & 2 & 0.051 & 0.026 & 1.600 & 0.223 & 0.001 & 0.009 & 0.022 & 0.978 \\
\hline Error & 24 & 0.386 & 0.016 & & & 0.655 & 0.001 & & \\
\hline \multicolumn{10}{|c|}{ Profile of soil level $(30.0-14.0 \mathrm{~cm})$} \\
\hline Intercept & 1 & 4.341 & 4.341 & 606.893 & $0.000 *$ & 2.505 & 2.505 & 175.393 & $0.000 *$ \\
\hline Genotype (GE) & 1 & 0.041 & 0.041 & 5.713 & $0.025^{*}$ & 0.006 & 0.006 & 0.404 & 0.531 \\
\hline $\begin{array}{l}\text { Soil compaction } \\
\text { (SC) }\end{array}$ & 1 & 0.020 & 0.020 & 2.828 & 0.105 & 0.095 & 0.095 & 6.646 & $0.016^{*}$ \\
\hline Treatment (TR) & 2 & 1.361 & 0.680 & 95.108 & $0.000 *$ & 0.658 & 0.329 & 23.024 & $0.000 *$ \\
\hline $\mathrm{GE} \times \mathrm{SC}$ & 1 & 0.039 & 0.039 & 5.534 & $0.027 *$ & 0.002 & 0.002 & 0.168 & 0.685 \\
\hline $\mathrm{GE} \times \mathrm{TR}$ & 2 & 0.068 & 0.034 & 4.788 & $0.017 *$ & 0.015 & 0.007 & 0.517 & 0.603 \\
\hline $\mathrm{SC} \times \mathrm{TR}$ & 2 & 0.064 & 0.032 & 4.459 & $0.022^{*}$ & 0.045 & 0.023 & 1.594 & 0.224 \\
\hline $\mathrm{GE} \times \mathrm{SC} \times \mathrm{TR}$ & 2 & 0.049 & 0.025 & 3.457 & $0.048^{*}$ & 0.006 & 0.003 & 0.212 & 0.810 \\
\hline Error & 24 & 0.172 & 0.007 & & & 0.343 & 0.014 & & \\
\hline
\end{tabular}

According to Yoshida and Hasegawa (1982) traditional drought-resistant dryland rice cultivars have thick roots and that thicker roots have been associated with deep root systems.

Effects of soil compaction on dry matter of maize and triticale genotypes differing in susceptibility to environmental stresses

Four weeks of growth under conditions of severe (SSC) soil compaction, in comparison to treatment with low soil compaction (LSC), decreased dry matter (DM) of a shoot $(\mathrm{S})$, roots $(\mathrm{R})$, total seedling dry matter $(\mathrm{S}+\mathrm{R})$ and shoot to root ratio (S/R) (Table 4) resulted in stress sensitive genotypes (Ancora, CHD-147) and resistant
(Tina, CHD-247). After growth by 28 days in the SSC treatment the decrease of growth parameters were greater for triticale than for maize. In this treatment shoot (S) dry matter decreased by about 23 and $13 \%$ in triticale genotypes CHD-147 and CHD-247, respectively, and by 8 and $7 \%$ in maize genotypes Ankora and Tina, respectively. The decrease in root $(\mathrm{R})$ dry matter for triticale genotypes CHD-147 and CHD-247 was 18 and $7 \%$, respectively, and for maize genotypes Ankora and Tina was about 6 and $5 \%$, respectively. For triticale stress sensitive genotype (CHD-147) the decrease of S/R ratio was statistically significant and for both maize genotypes and for triticale stress-resistant genotype the decrease of $\mathrm{S} / \mathrm{R}$ ratio were also observed, but differences were not significant. 
Table 8 Number and length particular components of root system development by stress sensitive (Ankora, CHD-147) and resistant (Tina, CHD-247) maize and triticale genotypes grown in two level of soil compactions (LSC, SSC) and subjected by 2 weeks to drought (D) or waterlogging $(\mathrm{W})$ stress

\begin{tabular}{|c|c|c|c|c|c|c|c|c|c|c|c|c|}
\hline \multirow[t]{4}{*}{ Genotype } & \multirow[t]{4}{*}{ Treatment } & \multicolumn{11}{|c|}{ Components of root system } \\
\hline & & \multirow{3}{*}{$\begin{array}{l}\text { Seminal } \\
\text { Length }\end{array}$} & \multicolumn{6}{|c|}{ Laterals developed on seminal root } & \multirow{3}{*}{$\begin{array}{l}\text { Seminal } \\
\text { adventitious* } \\
\text { Length }\end{array}$} & \multirow{2}{*}{\multicolumn{3}{|c|}{ Nodal }} \\
\hline & & & \multicolumn{3}{|l|}{ L-type } & \multicolumn{3}{|l|}{ S-type } & & & & \\
\hline & & & Number & Length & $\begin{array}{l}\text { Mean } \\
\text { length }\end{array}$ & Number & Length & $\begin{array}{l}\text { Mean } \\
\text { length }\end{array}$ & & Number & Length & $\begin{array}{l}\text { Mean } \\
\text { length }\end{array}$ \\
\hline \multicolumn{13}{|l|}{ Maize } \\
\hline \multirow[t]{6}{*}{ Ankora } & LSC & $35.0 \mathrm{a}$ & $341.7 \mathrm{a}$ & $118.3 \mathrm{c}$ & $2.9 \mathrm{a}$ & $67.8 \mathrm{a}$ & $58.0 \mathrm{a}$ & $1.2 \mathrm{a}$ & $65.0 \mathrm{a}$ & $8.9 \mathrm{a}$ & $131.3 \mathrm{a}$ & $14.8 \mathrm{a}$ \\
\hline & $\mathrm{LSC}+\mathrm{D}$ & $33.2 \mathrm{~b}$ & $318.0 \mathrm{~b}$ & $151.4 \mathrm{a}$ & $2.1 \mathrm{~b}$ & $55.0 \mathrm{~b}$ & $60.5 \mathrm{a}$ & $0.9 \mathrm{~b}$ & $55.1 \mathrm{~b}$ & $7.0 \mathrm{~b}$ & $100.3 \mathrm{c}$ & $14.3 \mathrm{a}$ \\
\hline & $\mathrm{LSC}+\mathrm{W}$ & $25.1 \mathrm{~d}$ & $290.2 \mathrm{c}$ & $139.5 \mathrm{~b}$ & $2.1 \mathrm{~b}$ & $41.0 \mathrm{c}$ & $41.4 \mathrm{c}$ & $1.0 \mathrm{ab}$ & $42.0 \mathrm{c}$ & $6.2 \mathrm{~b}$ & $76.7 \mathrm{~d}$ & $12.4 \mathrm{~b}$ \\
\hline & SSC & $30.1 \mathrm{c}$ & $307.8 \mathrm{~b}$ & $107.8 \mathrm{~d}$ & $2.9 \mathrm{a}$ & $55.2 \mathrm{~b}$ & $48.2 \mathrm{~b}$ & $1.1 \mathrm{a}$ & $55.1 \mathrm{~b}$ & $7.9 \mathrm{ab}$ & $118.1 \mathrm{~b}$ & $14.9 \mathrm{a}$ \\
\hline & $\mathrm{SSC}+\mathrm{D}$ & $25.1 \mathrm{~d}$ & $265.2 \mathrm{~d}$ & $119.6 \mathrm{~d}$ & $2.2 \mathrm{~b}$ & $41.8 \mathrm{c}$ & $39.3 \mathrm{c}$ & $1.1 \mathrm{a}$ & $42.1 \mathrm{c}$ & $5.3 \mathrm{c}$ & $76.3 \mathrm{~d}$ & $14.4 \mathrm{a}$ \\
\hline & $\mathrm{SSC}+\mathrm{W}$ & $16.0 \mathrm{e}$ & $229.0 \mathrm{e}$ & $88.6 \mathrm{e}$ & $2.1 \mathrm{~b}$ & $28.4 \mathrm{~d}$ & $25.8 \mathrm{~d}$ & $1.1 \mathrm{a}$ & $31.2 \mathrm{~d}$ & $4.0 \mathrm{~d}$ & $49.0 \mathrm{e}$ & $12.3 \mathrm{~b}$ \\
\hline \multirow[t]{6}{*}{ Tina } & LSC & $38.0 \mathrm{a}$ & $390.1 \mathrm{a}$ & $144.2 \mathrm{~b}$ & $2.7 \mathrm{a}$ & $81.2 \mathrm{a}$ & $59.4 \mathrm{a}$ & $1.4 \mathrm{a}$ & $62.1 \mathrm{a}$ & $9.4 \mathrm{a}$ & $122.3 \mathrm{a}$ & $13.0 \mathrm{c}$ \\
\hline & $\mathrm{LSC}+\mathrm{D}$ & $36.2 \mathrm{ab}$ & $350.0 \mathrm{~b}$ & $155.0 \mathrm{a}$ & $2.3 \mathrm{c}$ & $70.0 \mathrm{~b}$ & $55.0 \mathrm{a}$ & $1.3 \mathrm{ab}$ & $53.0 \mathrm{~b}$ & $7.5 \mathrm{c}$ & $106.2 \mathrm{c}$ & $14.2 \mathrm{~b}$ \\
\hline & $\mathrm{LSC}+\mathrm{W}$ & $29.1 \mathrm{c}$ & $311.2 \mathrm{c}$ & $149.2 \mathrm{~b}$ & $2.1 \mathrm{~d}$ & $71.1 \mathrm{~b}$ & $56.0 \mathrm{a}$ & $1.3 \mathrm{ab}$ & $42.0 \mathrm{c}$ & $7.6 \mathrm{c}$ & $107.5 \mathrm{c}$ & $14.1 \mathrm{~b}$ \\
\hline & SSC & $35.1 \mathrm{~b}$ & $351.0 \mathrm{~b}$ & $130.0 \mathrm{c}$ & $2.7 \mathrm{a}$ & $71.2 \mathrm{~b}$ & $56.1 \mathrm{a}$ & $1.3 \mathrm{ab}$ & $55.5 \mathrm{~b}$ & $8.5 \mathrm{~b}$ & $111.0 \mathrm{~b}$ & $13.1 \mathrm{c}$ \\
\hline & $\mathrm{SSC}+\mathrm{D}$ & $29.2 \mathrm{c}$ & $307.8 \mathrm{~cd}$ & $125.1 \mathrm{~d}$ & $2.5 \mathrm{bc}$ & $58.2 \mathrm{c}$ & $49.1 \mathrm{~b}$ & $1.2 \mathrm{~b}$ & $48.2 \mathrm{~b}$ & $5.3 \mathrm{e}$ & $83.1 \mathrm{e}$ & $15.7 \mathrm{a}$ \\
\hline & $\mathrm{SSC}+\mathrm{W}$ & $18.9 \mathrm{~d}$ & $295.3 \mathrm{~d}$ & $128.1 \mathrm{~cd}$ & $2.3 \mathrm{c}$ & $62.5 \mathrm{c}$ & $51.1 \mathrm{~b}$ & $1.2 \mathrm{~b}$ & $36.3 \mathrm{~d}$ & $6.8 \mathrm{~d}$ & $93.1 \mathrm{~d}$ & $13.7 \mathrm{c}$ \\
\hline \multicolumn{13}{|l|}{ Triticale } \\
\hline \multirow{6}{*}{$\begin{array}{r}\text { CHD- } \\
147\end{array}$} & LSC & $22.8 \mathrm{a}$ & $222.1 \mathrm{a}$ & $84.3 \mathrm{~b}$ & $2.6 \mathrm{a}$ & $44.1 \mathrm{a}$ & $43.2 \mathrm{a}$ & $1.0 \mathrm{ab}$ & $42.3 \mathrm{a}$ & $6.7 \mathrm{a}$ & $91.3 \mathrm{a}$ & $13.6 \mathrm{ab}$ \\
\hline & $\mathrm{LSC}+\mathrm{D}$ & $21.6 \mathrm{a}$ & $218.1 \mathrm{a}$ & $98.4 \mathrm{a}$ & $2.2 \mathrm{~cd}$ & $35.8 \mathrm{~b}$ & $39.3 \mathrm{~b}$ & $0.9 \mathrm{~b}$ & $35.8 \mathrm{~b}$ & $5.3 \mathrm{~b}$ & $69.8 \mathrm{c}$ & $13.2 \mathrm{c}$ \\
\hline & $\mathrm{LSC}+\mathrm{W}$ & $16.3 \mathrm{c}$ & $188.6 \mathrm{~b}$ & $90.7 \mathrm{~b}$ & $2.1 \mathrm{~d}$ & $26.7 \mathrm{c}$ & $31.0 \mathrm{c}$ & $0.9 \mathrm{~b}$ & $27.3 \mathrm{c}$ & $4.7 \mathrm{c}$ & $53.3 \mathrm{~d}$ & $11.3 \mathrm{~d}$ \\
\hline & SSC & $18.4 \mathrm{~b}$ & $189.0 \mathrm{~b}$ & $72.6 \mathrm{c}$ & $2.6 \mathrm{a}$ & $33.7 \mathrm{~b}$ & $33.7 \mathrm{c}$ & $1.0 \mathrm{ab}$ & $33.7 \mathrm{~b}$ & $5.6 \mathrm{~b}$ & $77.6 \mathrm{~b}$ & $13.9 \mathrm{a}$ \\
\hline & $\mathrm{SSC}+\mathrm{D}$ & $15.5 \mathrm{c}$ & $173.2 \mathrm{c}$ & $73.8 \mathrm{c}$ & $2.3 \mathrm{~b}$ & $25.7 \mathrm{c}$ & $24.0 \mathrm{~d}$ & $1.1 \mathrm{a}$ & $22.7 \mathrm{~d}$ & $3.8 \mathrm{~d}$ & $50.3 \mathrm{~d}$ & $13.3 \mathrm{bc}$ \\
\hline & $\mathrm{SSC}+\mathrm{W}$ & $10.1 \mathrm{~d}$ & $145.1 \mathrm{~d}$ & $55.8 \mathrm{~d}$ & $2.6 \mathrm{a}$ & $17.9 \mathrm{~d}$ & $16.0 \mathrm{e}$ & $1.1 \mathrm{a}$ & $15.0 \mathrm{e}$ & $3.0 \mathrm{e}$ & $33.0 \mathrm{e}$ & $11.1 \mathrm{~d}$ \\
\hline \multirow{6}{*}{$\begin{array}{c}\text { CHD- } \\
247\end{array}$} & LSC & $21.4 \mathrm{a}$ & $209.0 \mathrm{a}$ & $79.3 \mathrm{~b}$ & $2.6 \mathrm{~b}$ & $41.5 \mathrm{a}$ & $40.7 \mathrm{a}$ & $1.0 \mathrm{ab}$ & $39.8 \mathrm{a}$ & $5.4 \mathrm{a}$ & $75.5 \mathrm{a}$ & $13.9 \mathrm{~b}$ \\
\hline & $\mathrm{LSC}+\mathrm{D}$ & $20.3 \mathrm{~b}$ & $204.8 \mathrm{~b}$ & $92.4 \mathrm{a}$ & $2.2 \mathrm{~cd}$ & $33.6 \mathrm{~b}$ & $36.9 \mathrm{a}$ & $0.9 \mathrm{~b}$ & $33.6 \mathrm{~b}$ & $4.3 \mathrm{~b}$ & $59.0 \mathrm{c}$ & $13.8 \mathrm{~b}$ \\
\hline & $\mathrm{LSC}+\mathrm{W}$ & $15.0 \mathrm{~d}$ & $173.2 \mathrm{c}$ & $83.3 \mathrm{~b}$ & $2.1 \mathrm{~d}$ & $24.5 \mathrm{c}$ & $28.5 \mathrm{~b}$ & $0.9 \mathrm{~b}$ & $25.1 \mathrm{c}$ & $3.7 \mathrm{c}$ & $44.4 \mathrm{~d}$ & $12.0 \mathrm{~d}$ \\
\hline & SSC & $18.2 \mathrm{c}$ & $158.8 \mathrm{~d}$ & $55.5 \mathrm{~cd}$ & $2.9 \mathrm{a}$ & $31.5 \mathrm{~b}$ & $28.0 \mathrm{~b}$ & $1.1 \mathrm{a}$ & $30.2 \mathrm{~b}$ & $4.6 \mathrm{~b}$ & $67.0 \mathrm{~b}$ & $14.6 \mathrm{a}$ \\
\hline & $\mathrm{SSC}+\mathrm{D}$ & $15.6 \mathrm{~d}$ & $137.2 \mathrm{e}$ & $59.9 \mathrm{c}$ & $2.3 \mathrm{c}$ & $22.5 \mathrm{c}$ & $22.2 \mathrm{~d}$ & $1.0 \mathrm{ab}$ & $22.5 \mathrm{c}$ & $3.3 \mathrm{c}$ & $49.5 \mathrm{~d}$ & $15.0 \mathrm{a}$ \\
\hline & $\mathrm{SSC}+\mathrm{W}$ & $11.2 \mathrm{e}$ & $139.0 \mathrm{e}$ & $54.4 \mathrm{~cd}$ & $2.6 \mathrm{~b}$ & $18.0 \mathrm{~d}$ & $18.7 \mathrm{~d}$ & $1.0 \mathrm{ab}$ & $15.5 \mathrm{~d}$ & $2.8 \mathrm{~d}$ & $36.5 \mathrm{e}$ & $13.0 \mathrm{c}$ \\
\hline
\end{tabular}

In columns (genotype) with similar letters do not differ significantly at 0.05 probability level according to Duncan's multiple range test

* Total length of 2 or 3 seminal adventitious roots of maize and triticale genotypes, respectively

Multistress effects of soil compaction (SC)

with drought (D) or waterlogging (W) on a growth

of maize and triticale genotypes differing

in susceptibility to environmental stresses

Soil drought (D) or waterlogging (W) from 14th till 28th day of seedlings growth caused greater decrease of dry matter of shoot (S), roots (R), and $\mathrm{S}+\mathrm{R}$ in seedlings grown in SSC than LSC. In seedlings grown in severe soil compaction and in waterlogging $(\mathrm{SSC}+\mathrm{W})$ the decrease in dry matter of $S, R$ and $S+R$ was greater than in treatment SSC $+\mathrm{D}$ especially for sensitive maize hybrid Ankora. However, in triticale differences in decrease of dry matter between sensitive (CHD 147) and resistant genotypes CHD 247 were smaller. The data of root penetration index (RPI) was examined using ANOVA analysis of variance and is shown in Table 5. For both species there were significant differences among genotypes (GE) and treatments (TR) and only for maize for soil compaction (SC) and interactions GE $\times$ TR were also significant. Obtained results indicate the existence of genetic variation of stress susceptibility between genotypes of maize and triticale and possibility of selection of genotypes in penetration of roots in soil profile.

Results obtained in this work confirm that severe levels of soil compaction led to reduction in shoot and root 


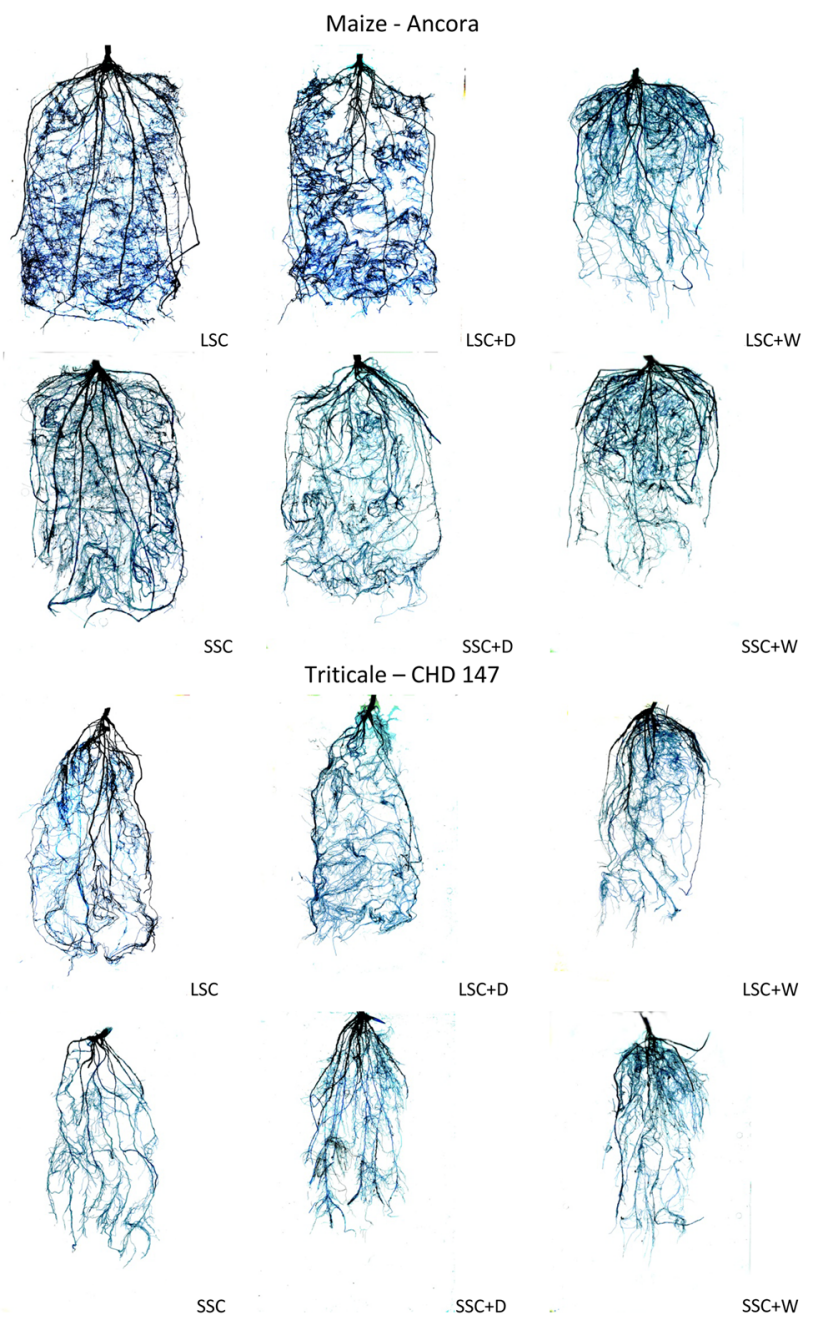

Fig. 2 Root system profiles of 28-days maize (Ankora) and triticale (CHD-247) under two levels of soil compaction (low, LSC; severe, SSC) and after applied exposure 2-week drought (D) or waterlogging (W)

growth. Several authors have pointed out effects of soil impedance on reduction of plant dry matter, size, and yield (Andrade et al. 1993; Lipiec et al. 1993; Whalley and Dexter 1994). Reduction in dry matter of maize shoots in compact soil conditions was mostly due to reduction in leaf area, stem diameter and plant height (Lipiec et al. 1996) (Tables 6, 7).

\section{Changes in root system structure}

In comparison to low level of soil compaction (LSC) severe level (SSC) influenced the length of seminal and seminal adventitious roots, the number and length of $\mathrm{L}$ and S-type lateral roots developed on seminal roots and nodal roots (Table 8; Fig. 2). In both species restriction effects of soil compactions on number and length of roots was severer in sensitive (Ankora, CHD-147) than in resistant (Tina, CHD-247) genotypes. In SSC, length of the seminal root decreased by 14.0 and $8 \%$ in maize (Ankora, Tina) and 19 and $15 \%$ in triticale (CHD-147, CHD-247), respectively. The total length of seminal adventitious roots decreased in maize genotypes Ankora by about $15 \%$ and in Tina $11 \%$ in triticale CHD-147 and about $20 \%$, and in CHD-247 about $24 \%$, respectively. Higher decrease of total number and length of nodal roots was observed in treatments SSC in comparison to treatment LSC. In Ankora, decrease in number and length were about $11 \%$, and in Tina about $10 \%$. In triticale decrease in number of nodal roots in CHD-147 and CHD-247 genotypes were 16 and $15 \%$, respectively, and in length 16 and $11 \%$, respectively. Soil compaction also reduced the number of both L- and S-type of lateral roots developed on seminal root. The number was more severely restricted in S-type lateral roots than in L-type roots regardless of species. The restriction in lateral root propagation was greater in triticale. Induced of drought (D) or waterlogging (W) for genotypes grown in LSC and SSC treatments caused higher decrease of number and length of particular components of root system structure. In both species decrease of root number and length in plants grown under waterlogging (W) was higher than plants grown under drought (D). Moreover, decrease in number and length of particular components of roots system was greater in genotypes for which values of RPA and RPI indexes were lower (Ankora, CHD147) comparing to genotypes with higher values of these indexes (Tina, CHD-247).

Iijima and Kono (1991) examined the effect of soil compaction on a root growth as discriminating root components in rice and maize. In their research, responses of root types and root system to soil compaction were clearly different between rice with "concentrated" type of root system and maize with the "scattered" type. Along with the present study, a consistent trend has been found that a species with "concentrated" type of root system showed less restriction of roots growth due to high soil compaction compared to "scattered" type, as shown in a comparison between triticale and maize. The heavy suppression of lateral root growth would affect plant nutrition and water relation because the soil compaction resulted in decreased size of root system, increased irregularity of root distribution and thus in greater distances for the transport of water and nutrients to the nearest roots (Tardieu 1991; Lipiec et al. 1996). Also the restriction in number and length of each root type in conditions of high soil impedance accompanied by a decrease in leaf water potential, decrease in photosynthesis, and changes in stomata conductance and contents of internal carbon dioxide (Grzesiak et al. 1999). Highlighting the water relation and gas exchange rate of plants under soil stresses, many studies indicate that leaf water status and gas exchange parameters 
(especially stomata behavior) are influenced through several mechanisms (Lipiec et al. 1996). According to Masle (2002) root-borne signals affect the rate of development in the apical meristem, cell division and cell expansion in the expanding leaves and they induce stomatal behavior.

\section{Conclusions}

In cereal species exists interspecific differences in growth responses to environmental stresses. In this study, we discussed various viewpoints on changes in root system structure of maize and triticale genotypes seedlings. Both, soil compaction and periodical soil drought or waterlogging caused, in both species, a decrease of shoot and roots dry matter and changes in roots distribution in the soil profile. Changes of growth traits were higher in genotypes with high stress susceptibility indexes and low ability to soil root penetration. Future study are required to study the characteristic of physiological processes, anatomical and morphological changes in particular components of root system, roots distribution and roots extension rate in plants grown in the conditions soil stress.

Authors contribution MTG, AO, GR, SG and TH designed the research; MTG, AO, GR, KH and FJ conducted the research; MTG, AO, GR, AR, SG, FJ and TH analyzed the data; MTG, AO, GR, FJ, SG and KH wrote the paper; MTG had primary responsibility for the final content. All authors have read and approved the final manuscript.

Acknowledgments The authors are grateful to the National Science Centre (NCN) for financial support (Project No. N N310 782540). Also the authors express gratitude to the "Pioneer" Overseas GMBH, Vienna, (Austria), the Garst Seed Company, Iowa (USA), the Agriculture Canada, Agassiz Research Station, (Canada), SEMPOL Holding, Trnava, (Slovakia), DANKO, Choryn and IHAR, Małyszyn (Poland) for the grain of maize and triticale genotypes used in experiments.

Open Access This article is distributed under the terms of the Creative Commons Attribution License which permits any use, distribution, and reproduction in any medium, provided the original author(s) and the source are credited.

\section{References}

Andrade A, Wolfe DW, Ferens E (1993) Leaf expansion, photosynthesis and water relations of sunflower plants grown on compacted soil. Plant Soil 149:175-184

Ashraf M (2010) Inducing drought tolerance in plants: recent advances. Biotech Adv 28:199-238

Assaeed AM, McGowan M, Hebblethwaite PD, Brereton JC (1990) Effect of soil compaction on growth, yield and light interception of selected crops. Ann Appl Biol 117:653-667
Atwell BJ (1993) Response of roots to mechanical impedance. Environ Exp Bot 33:27-40

Busscher WJ, Sojka RE, Doty CW (1986) Residual effects of tillage on coastal plain soil strength. Soil Sci 2:144-148

Chan G, Weil RR (2010) Penetration of cover crop roots through compacted soil. Plant Soil 331:31-43

Chang TT, Armenta-soto JL, Mao CX, Peiris R, Loresto GC (1986) Genetic studies on the components of drought resistance in rice (Oryza sativa L.). In: Rice genetics IRRI. Los Banos, pp 389-398

Chaves MM, Pereira JS, Maroco J, Rodrigues ML, Ricardo CPP, Osorio LM, Carvalho I, Faria T, Pinheiro C (2002) How plants cope with water stress in the field? Photosynthesis and growth. Ann Bot 89:907-916

Clark LJ, Whalley WR, Barraclough PB (2003) How do roots penetrate strong soil. Plant Soil 255:93-104

Fageria NK, Balingar VC, Clark RB (2006) Physiology of crop production. The Haworth Press Inc., New York, London, Oxford, pp 23-60

Fischer RA, Maurer R (1978) Drought resistance in spring wheat cultivars. I. Grain yield response. Aust J Agric Res 29:897-907

Glinski J, Lipiec J (1990) Soil physical conditions and plant roots. CRC Press, Boca Raton

Golbashy M, Ebrahimi M, Khavari-Khorasani S, Choukan R (2010) Evaluation of drought tolerance of same corn (Zea mays L.) hybrids in Iran. Afr J Agric Res 5:2714-2719

Grzesiak S, Hura T, Grzesiak MT, Pieńkowski S (1999) The impact of limited soil moisture and waterlogging stress conditions on morphological and anatomical root traits in maize (Zea mays L.) hybrids of different drought tolerance. Acta Physiol Plant 21:305-315

Grzesiak S, Grzesiak MT, Filek W, Hura T, Stabryła J (2002) The impact of different soil moisture and soil compaction on the growth of triticale root system. Acta Physiol Plant 24:331-342

Grzesiak MT, Marcinska I, Janowiak F, Rzepka A, Hura T (2012) The relationship between seedling growth and grain yield under drought conditions in maize and triticale genotypes. Acta Physiol Plant 34:1757-1764

Grzesiak MT, Waligórski P, Janowiak F, Marcińska I, Hura K, Szczyrek P, Głąb T (2013) The relations between drought susceptibility index based on grain yield $\left(\mathrm{DSI}_{\mathrm{GY}}\right)$ and key physiological seedling traits in maize and triticale genotypes. Acta Physiol Plant 35:549-565

Grzesiak MT, Szczyrek P, Rut G, Ostrowska A, Hura K, Rzepka A, Hura T, Grzesiak S (2014) Interspecific differences in tolerance to a soil compaction, drought and waterlogging stresses among maize and triticale genotypes. J. Agric Crop Sci. JAC-04-20140108 (in press)

Hanson AD, Nelson ChE (1985) Water adaptation of crop to drought. In: Carlson PS (ed) The biology of crop productivity. Academic Press, New York, pp 79-149

Hillel D, van Bavel CHM (1976) Simulation of profile water storage as related to soil hydraulic properties. Soil Sci Soc Am J 40:807-815

Iijima M, Kono Y (1991) Interspecific differences of the root system structures of four cereal species as affected by soil compaction. Jpn J Crop Sci 60:130-138

Iijima M, Kono Y, Yamauchi A, Jr Pardales (1991) Effects of soil compaction on the development of rice and maize root system. Environ Exp Bot 30:333-342

Kasperbauer MJ, Busscher WJ (1991) Genotypic differences in cotton root penetration of a compacted subsoil layer. Crop Sci 31:1376-1378

Kono Y, Yamauchi A, Nonoyama T, Tatsumi T, Kawamura N (1987a) A revised system of root-soil interaction for laboratory work. Environ Control Biol 25:141-151 
Kono Y, Yamauchi A, Kawamura AN, Tatsumi J (1987b) Interspecific differences of the capacities of waterlogging and drought tolerance among summer cereals. Jpn. J Crop Sci 56:115-129

Larsson S, Górny AG (1988) Grain yield and drought resistance indices of oat cultivars in field rain shelter and laboratory experiments. J Agron Crop Sci 161:277-286

Lipiec J, Ishioka T, Hatano R, Sakuma T (1993) Effects of soil structural discontinuity on root and shoot growth and water use in maize. Plant Soil 157:65-74

Lipiec J, Ishioka T, Szustak A, Pietrusiewicz J, Stępniewski W (1996) Effects of soil compaction and transient oxygen deficiency on growth, water use and stomatal resistance in maize. Acta Agric Scand Sect B Soil Plant Sci 46:186-191

Masle J (1992) Genetic variation in the effects of root impedance on the growth and transpiration rates of wheat and barley. Aust J Plant Physiol 19:109-125

Masle J (2002) High soil strength: mechanical forces at play on root morphogenesis and in root:shoot signaling. In: Waisel Y, Eshel A, Kafkafi U (eds) Plant roots the hidden half. Marcel Dekker Inc, New York, Basel, pp 807-819

Materechera SA, Alston AM, Kirby JM, Dexter AR (1992) Influence of root diameter on the penetration of the seminal roots into a compacted sub soil. Plant Soil 144:297-303

Nayyar H, Gupta D (2006) Differential sensitivity of C3 and C4 plants to water deficit stress: association with oxidative stress and antioxidants. Environ Exp Bot 58:106-113

O‘Toole JC, Cruz RT (1983) Genotypic variation in epicuticular wax of rice. Crop Sci 23:392-394

Royo C, Abaza M, Blaneo R, Gareia del Moral LF (2000) Triticale grain growth and morphometry as affected by drought stress, late sowing and simulated drought stress. Aust J Plant Physiol 27:1051-1059

Tardieu F (1991) Spatial arrangement of maize roots in the field. In: McMichael BL, Person H (eds) Plant roots and their environment. Elsevier, Amsterdam, pp 506-514
Tardieu F, Katerji N (1991) Plant response to soil water reserve: consequences of the root system environment. Irrig Sci $12: 145-152$

Taylor HM, Gardner HR (1960) Use of wax substrates in root penetration studies. Soil Sci Soc Am Proc 24:79-81

Tu JC, Tan CS (1991) Effect on soil compaction on growth, yield and root rots of white beans in clay loam and sand loam soil. Soil Biol Biochem 23:233-238

Whalley WR, Dexter AR (1994) Root development and earthworm movement in relation to soil strength and structure. Arch Agron Soil Sci 38:1-40

Winter SR, Musick JT, Porter KB (1988) Evaluation of screening techniques for breeding drought-resistant winter wheat. Crop Sci 28:512-516

Witta S, Galiciab L, Liseca J, Cairnsc J, Tiessend A, Araus JL, Palacios-Rojas N, Ferniea AR (2012) Metabolic and phenotypic responses of greenhouse-grown maize hybrids to experimentally controlled drought stress. Mol Plant 5:401-417

Yamauchi A (1993) Significance of root system structure in relation to stress tolerance in cereal crop. Low-input sustainable crop production system in Asia. Korean Soc Crop Sci, Korea, pp 347-360

Yoshida S, Hasegawa S (1982) The rice root system: its development and function. Drought resistance in crop with emphasis on rice. IRRI Los Banos, Philippines, pp 97-114

Yu LX, Ray JD, O‘Toole JC, Nguyen HT (1995) Use of waxpetrolatum layer for screening rice root penetration. Crop Sci 35:684-687

Zagdanska B (1992) Physiological criteria for estimation of plant resistance to drought. Biul Inst Hod i Aklim Roślin 183:11-19 (in Polish) 